\title{
Individual Testimonies of Trans-individual Crisis: The Covid-19 Confinement Essay Film
}

\begin{abstract}
The COVID-19 pandemic, and the unprecedented confinement measures it prompted governments to take, has led to a boom of audiovisual testimonies of the numerous facets this global phenomenon has assumed. Some of the testimonies have taken the shape of essay films which embrace the topic of the restrictions imposed on access to the outside world, turning them into organizational principles and formal devices. In this article, I will comment on some of the specificities of the audiovisual by-products of the COVID-19 confinement and their approach to filmic representation of the spatial sense of self and to the audiovisual making of the political subject. I will approach a sample of these films, namely the "cinematic letters" proposed by the Cinémathèque Française during last spring's national lockdown, via two phenomena. The first is carceral experience and its various enunciations which, notwithstanding the overwrought parallels sometimes made with the pandemic-induced lockdown, can provide useful context for analyzing the relation between the forcibly secluded individual and the outside world. The second is the recording of voluntary social isolation-a particular thematic configuration of the essay film which converges with the COVID-19 confinement films in terms of discursive strategies and spatial problematization.
\end{abstract}

Keywords: pandemic media, essay film, carceral experience, (self-)confinement film, lettres de cinéma.

\section{Introduction}

During the current public health crisis brought about by the COVID-19 virus, one could have been reminded of Friedrich Kittler's trenchant opening phrase of the preface to his Gramophone, Film, Typewriter: "Media determine our situation" (xxxix). At first glance, linking Kittler's general diagnosis to our specific context may bring to mind the ubiquitous role media has played in the shaping,

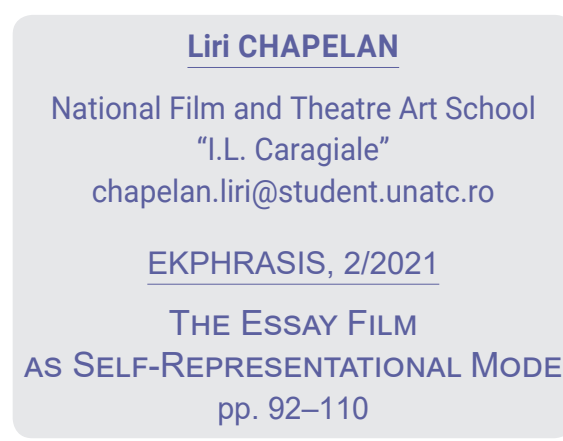

DOI: $10.24193 /$ ekphrasis.26.7

Published First Online: December 15, 2021 
exposition, visualization, enframing, deciphering of and coping with the pandemic, at individual as well as collective level. The pandemic impacted both what was already thought of as facets of our fluid and fast-evolving hyper-connected existences, like professional activities or entertainment, but also more deeply anchored, transhistorical practices, such as embodied contact with other social beings. It was a catalyst for already existing trends, the unexpected fertilizer that nourished the mediatic organism so effectively that it spread its extremities to domains that had previously seemed out of reach. Kittler's pronouncement is, however, less a verdict than an invitation to look dispassionately beyond the curtain of technological determinism or, for that matter, of any equally monolithic counterreaction the latter may elicit. The author in fact continues: "Media determine our situation, which-in spite or because of it-deserves a description." In the present article, I will attempt to contribute to such a description, not by surveying the excessively vast and heterogeneous mediascape changes engendered by the pandemic, but by focusing on a particular genre-the essay film.

I will postulate that the accelerated virtualization of media practices and, to a greater extent, the replacement of human-to-human with human-to-machine interactions during the COVID health crisis has impacted the content and form of essay films. I will begin my article by underlying the insights the analysis of another state of seclusion - the carceral experiencemay hold for the contextualization and interpretation of the audiovisual commentaries on forced confinement the lockdown measures have prompted. Subsequently, in order to point out the complex entwining of correspondences and disparities that links these commentaries to other types of media texts made under or tackling the topic of physical confinement, I will turn towards a particular thematic configuration of essay films, namely the diaristic account of an episode of self-isolation. I will develop both lines of argument by referring to a specific corpus of short films made during the first wave of preventive lockdowns, in early 2020. Assuredly, this game of mirrors between pandemic essay films and previously known states of confinement will not overlook the rift separating these experiences. For one, while “[...] parallels between being a 'prisoner' and being in lockdown at home have proliferated [especially] online, from formerly incarcerated people being asked to give advice on how to deal with quarantine to Ellen DeGeneres joking about being imprisoned in her mansion" (Tschanz and Hernandez 148), these are rooted in subjective perceptions, not in grounded analogies between the degrees of autonomy, the conditions of comfort or the social engagement allowed by each condition. Similarly, the audiovisual documentation of an episode of self-isolation is a thematic configuration in essayistic filmmaking which converges with COVID-19 confinement films in terms of discursive strategies, but which describes an essentially individual experience, while my objects of study are remarkable precisely because they depict a global, transindividual reality. Therefore, it is only through a transversal comparison, in which all terms act as migrating elements with fluid, non-normative traits, 
that I may be able to achieve a fruitfully speculative mapping of some of the influences that shape COVID-19 confinement essay films.

My corpus of pandemic essay films will consist of the so-called "cinematic letters" (lettres de cinéma $)^{1}$ showcased by the Cinémathèque Française during the first national lockdown, in the spring of 2020: short films varying from a few seconds to two or three dozens of minutes of free-form audiovisual comment on the situation, commissioned to or spontaneously proposed by various confirmed and burgeoning film and media artists. This corpus presents two advantages. First, it is easily accessible, as it was uploaded by the Cinémathèque to its open-access Vimeo account in a desire to contribute to the establishment of a quasi-instant video archive of the global manifestations of an exceptional historical event. Second, as opposed to most audiovisual snippets of lockdown which are scattered on social media or on video-sharing platforms, it is composed of short films that share for the most part related geo-cultural origins and aesthetic credos, which makes their grouping within the framework of this analysis less arbitrary. While they best offer a prismatic depiction of the first nationwide lockdown imposed in France in March 2020-so of an event with specific spatial, temporal, social and political coordinates-they also arguably point to larger trends in essay film production in the new global media context defined by the pandemic.

\section{Notes on the Pandemic Essay Film}

The two dimensions of the virus - as microorganism and as global sanitary concernwere situated at opposing ends of the scale spectrum, and yet they confronted the experts with the same challenge of translating scientific facts in visual terms which could be grasped by the general public. This challenge was mostly overcome, but the media was so prompt in digesting the virus, or at least in developing new configurations that could accommodate the new world order it had installed, that the risk of genealogical inversion arose. Instead of settling for the fact that original media forms emerged from the sanitary crisis, counternarratives affirmed it was media which had altogether created the sanitary crisis, in order to advance the economic interests of political and pharmacological elites. As Philipp Dominik Keidl and Laliv Melamed-two of the co-editors of one of the first and most comprehensive volumes of scholarly texts on the recent media transmutations happening in the context of the COVID-19 crisis-remark, "the pandemic was a heavily mediated event, if not a media event in itself.” (12). Their following assertion however, according to which

1 The appellation should be taken figuratively, as the films in question resemble open letters in their dialectic between private enunciation and public reception, but do not actually feature a cohesive epistolary form. 
"media operations or their instrumentality were deemed invisible or neutralized" (12) in public debates surrounding the pandemic, needs to be nuanced precisely in light of these widely circulated conspiracy theories which, for better or for worse, drew attention to the world-building capacities of the media apparatus.

Another specific discursive format which had a similar unveiling effect was the discourse of the self-a common practice in our exhibitive, undoubtedly narcissistic culture of social networks, and which was further reinforced, but also revalorized, by the measures of social distancing imposed by the competent authorities around the globe. Yvonne Zimmermann summarizes: "Pandemic precaution requires distance from others in real life. This is one side of the coin. The other side is close contact - with oneself [...] It is a contact that we didn't ask for any more than we asked for distance from others. Worse, this close contact with oneself comes at a moment when others are to be kept at a distance." (100). The communicative value of self-documentation is thus enhanced by the specific conditions of restricted contact with the others. In such a context, opening up one's intimacy to the public gaze is no longer seen as an act of exhibition, with its underlying presumption of ostentation and egocentricity, but one of solidarity, an invitation to join a dialogical exchange of imposed solitudes. When these pursuits take an audiovisual form, they logically fall into the category of the essay film, especially if one considers the genre's widely-acknowledged literary origins, namely Michel de Montaigne's pioneering use of the term to characterize those works whose "provisional and explorative nature as 'attempts,' 'tries,' or 'tests' [...] produce[d] views of, comments on, and judgments of his faltering memory, love, friendship, lying, a 'monstrous childe,' and a plethora of other common and uncommon questions picked almost haphazardly from a mind observing the world passing before and through it." (Alter and Corrigan 1). Most interestingly, Montaigne's essays were "imagined, to some extent, as an active intellectual exchange with [the author's] deceased friend Étienne de La Boétie” (Alter and Corrigan 1), thus also mirroring the topos of the monological address to the absent other(s), which is a structuring principle of many pandemic diaristic media texts. In the following pages, I will call them pandemic essay films. Such subdivision is needed to refine the scope of the broader category of pandemic media, which Keidl and Melamed intended as a terminological novelty reflecting the singularity of the world situation: "As a pattern, the media event frames our reading of media ubiquity and their forming of a crisis mode, yet the radical and unprecedented scale of global reaction [against COVID-19] and measures of distancing prompted new manifestations, termed here 'pandemic media'." (13).

Pandemic films raise questions of visibility and competitive strategies for the viewers' attention-drowned as they were by the considerable number of similarly formulated reflections on the global experience of mandatory physical distancing and home confinement, as well as according to the organizational logic of the channels through which they most often circulated, i.e., social networks and video-sharing platforms. Beyond this 
arises another issue that is worth considering, especially in relation to the existing theoretical considerations on audiovisual essays in the field of film studies. It is safe to say that before the COVID-19 pandemic, forced physical confinement was a circumstance that was very rarely represented audiovisually by those directly affected. Most contexts that involve the restriction of the basic freedom of movement-from institutionally-enforced situations such as imprisonment or internment in psychiatric facilities to criminal acts such as kidnappingare characterized as a power struggle between the detainer and the detainee. Accordingly, self-representational capabilities are among the highest stakes of the confrontation, as they mark the difference between the active, autonomous, functional individual and the obedient subject. The transition between the two states is to be obtained through the continuous mastery of the other's body - a perspective Michel Foucault traces back to the XVIIth and XVIIIth centuries, when a change operated

[at the level of] the object of the control: it was not or was no longer the signifying elements of behaviour or the language of the body, but the economy, the efficiency of movements, their internal organization; constraints bear upon the forces rather than upon the signs; [...] it implies an uninterrupted, constant coercion, supervising the process of the activity rather than its results [...]. These methods, which made possible the meticulous control of the operations of the body, which assured the constant subjection of its forces and imposed upon them a relation of docilityutility, might be called 'disciplines.' (Discipline and Punish 137)

Under these conditions, immaterial, interiorized modes of expression-most often based on sheer imagination and memorization-are the most accessible forms of resistance to the cancellation of individuality that is being pursued by the detainer. Physical inscriptions of any kind are deemed dangerous, as they have the potential to circulate outside the enclosed space that the detainee inhabits, and therefore to symbolically permeate the frontiers which separate it from the outside world. While certain types of transposition of the detainee's interior reality on a material basis, most notably writing and drawing, sometimes escape the surveillance of the detainer due to the fact that, in their barest form, they only need a very crude device (a surface of inscription, such as the floor, the walls, etc. and a scratching instrument, e.g., a scrap of metal, piece of cutlery, or even nails), the cumbersomeness of the audiovisual apparatus before the digital era made any equivalent attempt at selfrepresentation impossible. On the other hand, digital technologies are hardly autonomous, becoming fully operable only when they are part of intricate networks that can be easily severed at various nodal points by competent authorities. In countries such as France, there is a solid, albeit relatively recent tradition of putting audiovisual devices into the hands of inmates, as proved by a number of reports like "2011: état des lieux sur la place de l'image en milieu pénitentiaire" or "Image à voir, image à faire, guide de l'image animée en milieu 
pénitentiaire" (2013). But these practices are more akin to a rebranded Foucauldian discipline than to unrestrained expression of creativity, as they are closely scrutinized by the owners of the means of production and their results are not integrated in the normal distribution circuits, thus reducing their visibility to the confines of the prison communities that generated them.

Therefore, the global measures taken to prevent the spread of COVID-19 have created a set of circumstances that are in many ways an update to the conventional freedom privation situations that used to be a blind spot in audiovisual self-representation. In this case however, the update does not only involve an evolution of the technical infrastructure on which these strategies of self-representation rest upon or a shift in perspective regarding their merits and appropriateness to be incorporated to the sanctioned audiovisual discourse and, later, to its archive. More notably, it has also modified the core of forced confinement, namely the power struggle between detainer and detainee. First, the moral grounds on which the two entities stand are vastly similar, in as much as both see the epidemic as harmful and having to be contained; consequently, the detained cannot experience their confinement as penalty for antisocial behavior-perspective which is central to the formation of the prisoner's identity. Second, the spatial restrictions play out in a familiar environment (the confines of one's own residence) and are not physically enforced unless one tries to breach the rules, which further blurs the contours of the detaining authority. What remains is a much more diffuse sense of injustice which is often oriented towards the perceived failings of the political system as a whole.

\section{The Politics of the Caged Bird: The Experience of Imprisonment and the Pandemic Essay Film}

Other means of expression may however more easily avoid the rigors befalling audiovisual self-representation in carceral settings. For example, among the reasons that may be advanced to explain the comparative impunity of writing inside the walls of detention centers are its relative ease of completion even with very limited means, as mentioned previously, but also its long genealogy. Such activity has by now become ingrained in the uses and customs of the "complete prison universe" (Breytenbach 276), due in no small portion to the validation of prison literature in the 'outside world,' as "an extant, global genre defined by subject and the relevant experience of its authors." (Larson 143). In an analysis which is focused on the specific case of English prison writing, but which may well be applicable to the Western world at large, ${ }^{2}$ Thomas $S$. Freeman contends that in the early modern period, a number

2 Different geo-cultural contexts suppose other evolutions of prison literature which are outside the scope of this article. 
of conditions, such as growing alphabetization, the generalization of printed media, and an increase of the number of prisoners-among whom were a non-negligible amount of members of the cultural elite-converged to make prison writing a distinct literary configuration. As an essential first point, Freeman notes the epistemological distance which separates the contemporary reader from prison texts penned as far as the XVIth century, distance which is principally caused by irreconcilable perspectives on the nature of the individuals confined inside prison walls. Prior to the mid-1500s, criminals were perceived as transgressing the rule of God, but their status of sinners would not automatically debase them in comparison with the 'functional' members of society; rather, it would symbolically reinforce their belonging to an essentially flawed humanity. Gradually, however, "crime came to be seen as an offense against the social order, [and thus] the criminal was seen as being outside of society and inherently different from its other members." (Freeman 137). Modern prison writing was shaped in the wake of the secularization of the logic of law and its impact on the status of prisoners. The expanding trend of carceral autobiography became first and foremost a manner of reestablishing contact with the outside, of reintegrating, albeit only discursively, the dynamics of a social organism that was felt to exist beyond (and even in opposition to) the judicial system that had inflicted punishment:

[...] relocating the self from the prison into alternative relationships, the prison writer never writes simply of or for him or herself. Writing into a resistant context is an act of dissociation, of verbal doubling. The position from which the prison writer writes makes inevitable, even if not always self-conscious, that the most personal expression will speak back to the system that places human beings inside cells. [...] Because the prison writer's autobiography is always also an implicit testament to the success or failure of the system of justice that has placed her inside a cell, the 'I' of the prison testament is always at once that of one human being writing the self back into language and into the communal identity that language offers, and that of any man or woman resisting the stone beneath their feet, the bars between their hands, and the scars across their backs—-that is, an effective 'we.' (Larson 148)

The prisoners' sense of identity is therefore dependent on their ability to situate themselves on a common plane with the rightful members of society, a plane from which they can willfully decide whether to abide by or further disrespect dominant ethical and legal standards. This symbolic grounding is best achieved through the subject's self-construction as enunciator and the establishment of a (at least imaginary) dialogical situation with the extracarceral world conceived not in terms of institutional structures and rigid moral hierarchies, but of receptive individuals who are presumably also oppressed by the very system that is depriving the prisoner of his freedom. There is a pertinent parallel to be drawn between the inmate's efforts to resist uprooting from society as depicted above by Larson and attempts 
to identify the main discursive strategies of the essay film, as does Laura Rascaroli amongst others when she states that

[...] the "I" of the essay film always clearly and strongly implicates a "you" [...]. "You" is called upon to participate and share the enunciator's reflections. It is important to understand that this "you" is not a generic audience, but an embodied spectator. The essay film constructs such a spectatorial position by adopting a certain rhetorical structure: rather than answering all the questions that it raises, and delivering a complete, "closed" argument, the essay's rhetoric is such that it opens up problems, and interrogates the spectator; instead of guiding her through emotional and intellectual responses, the essay urges her to engage individually with the film, and reflect on the same subject matter the author is musing about. This structure accounts for the "openness" of the essay film. (185)

While inmates are not denied the barest of existences, they are banned from participating in the decision-making process that shapes their living conditions. The disciplinary procedures Foucault emphasizes are not just instruments used to ensure the prisoners' docility, but constitute first and foremost the sensorial reality of their everyday experience. At different levels, these "microphysics of power" (Discipline and Punish 26) both dissociate and connect the carceral condition and its creative expression and the experience of lockdown as showcased by the videos gathered by the Cinémathèque Française. On the one hand, the creative agency of the contemporary filmmakers was restricted by the health crisis, as film productions, like most other 'non-essential' group activities, were halted across the globe in the effort to stop the transmission of the virus. But the same extraordinary circumstances also enlarged the spectrum of their practice, by introducing a new assortment of concrete situations and of corollary interior states that demanded to be documented, and of opportunities to exhibit their products. The "cinematic letters" of the Cinémathèque Française are one illustration of the new configuration of film diffusion, which offers a much more generous place to short, spontaneous content. Even more significantly, they attest to the shift in perspective happening in institutions habitually commissioned to preserve the ideologically-biased, burdensome corpus deemed as heritage, and which are now increasingly turning towards acting as deposits and curators of shifting, non-historically-validated fragments of the present. Knowing that the authors of the "cinematic letters" of the Cinémathèque Française benefited from institutional support and thus had the tools to harness the transformations of the mediascape, in addition to having the basic right to freedom of expression, it is of course improper to establish a rigorous parallel between these films and forms of "carceral aesthetics" (Fleetwood 2). Regarding the latter, "the carceral medium is not a safe [creative] space, [and as such] the act of [creation] is exposed, threatened, obstructed, forced into clandestinity, likely to be controlled and forbidden, experienced and assumed by the actors 
in all its material precarity" (Méchoulan, no pag.). However, the novelty of global-scale home confinement and the anxiogenic indeterminacy of the nature of the virus leading to chaotic responses of governments across the world contributed to the emergence of an "involving context": a context which "by fostering an emotional and social restlessness, as well as creating a shared experience and a feeling of identification, [...] encourages stances, judgements and reactions on subjects that affect or disturb us." (Tschanz and Hernandez 149). Such a context validates the emotional foundation of the otherwise factually inaccurate parallel between the COVID-19 lockdown and the prison experience. On a corporeal level, both sets of circumstances are linked by the phenomenological dimension of the prolonged experience of an enclosed, invariable space and the inescapable cycles of repetition it provokes. In accordance, a number of the "cinematic letters" are concerned with the issue of routine, which must be avoided, tamed or even systematically shattered, as well as with its reversal, change, which is charted, celebrated and eventually routinized.

Olga Prud'homme-Farges's From my Window / De ma fenêtre (2020) is an adequate example of how impromptu action becomes formulaic not only at the level of the signified, but, most acutely, at that of the cinematographic language employed to depict spontaneity. Prud'homme-Farges chronicles her attempts to maintain a social bond with her neighbors during the confinement period. The narrow Parisian street where she lives becomes a stage for contactless, yet very physical acts of communication: starting with the surprise birthday party the filmmaker throws for her teenage daughter, on which occasion a number of neighbors show up at windows, singing and clapping; the gathering developing into a daily event, centered around the usually collective acts of listening to music and dancing. The evenings are regularly enlivened by variations around the same theme of bridging the gap between people inhabiting the same space and sharing the same bewildering experience of being confined to it, yet separate from the others: masquerade parties, messages sent on a wire passed from one balcony to the other, chorus sessions, etc. Prud'homme-Farges does not only initiate these activities, she also records them and, in doing so, is confronted with a difficulty she does not thematize, but which is nonetheless relevant to the present discussion: that of being limited not only in space, but also, as a consequence, in language and more precisely in audiovisual language. If contemporary crises oftentimes reside in a handful of iconic images that inevitably become goods on the symbolic, epistemological and economic markets, few give rise to their own grammars, to forms that can match the singularity of their contents. Prud'homme-Farges's "cinematic letter", as many others in the corpus, fails to transform the physical restrictions which the author and her camera are subjected to into grounds for a rigorous aesthetic parti-pris. Instead, From my window exhibits a very accessible filming and editing style, with clear emotional cues (e.g., the frequent intertitles, the intercalation of still images which are being slowly zoomed-in) which reminds one of most amateur videos posted on social networks, in their mixture of gaucheness and aesthetic self-consciousness. 
Prud'homme-Farges's film is certainly not the only one that is eagerly turned towards the outside, through the mediation of the frame of the window. Guided by Gaston Bachelard's dialectics of interior and exterior spaces, Shekar Deshpande asserts that

[...] the significance of the window comes from its function to establish a separation of the inside from the outside, and public from the private. [...] Windows and cinema are metaphors and vehicles for each other, both media and technologies to examine the inside and the outside. Cinema is a window; it sees through a window; it is a window to other worlds; it comes to us as a window. It is not surprising that the pandemic supercharged the materiality of windows. An object of everyday familiarity, the pandemic turned windows into an important threshold to a world gripped by fear, rules, and caution. (no pag.)

Danielle Arbid's Outside (2020) explores the window in its more voyeuristic - and also socially violent-sense: as a surface that allows to see, but hardly allows to be seen, because of its location, towering the scene being observed, and of the very limited access it gives to the interior space when looked at from the outside. Arbid's "cinematic letter" is composed of short glimpses of the existence of a vagrant girl, who has temporarily settled in front of the filmmaker's block of flats. Arbid observes her interactions with other homeless youngsters, speculates on her identity, on the reasons behind her destitution. She films everything vertically, inscribing her thoughts directly on the image with a disproportionate font. The excessive height and bulkiness of the written text act not only as a reference to the aesthetics of social media (which shapes Olga Prud'homme-Farges's film as well), and especially of short video platforms such as Tik-Tok or Snapchat, but also emphasize the pondering of the interpretative act in the representation of the outside world. In forced seclusion, whether behind or beyond prison walls, the creative gesture is a tentative juncture with the exterior, and narrating is a way of affirming one's connection with the others, for it "gives an 'I' to the body, by 'producing' it through the objectivity of what 'appears'. But the body is what gestures towards the other and inscribes in the visible [...] the expectation of a respondent" (Méchoulan, no pag.). The cameraman's body is not strictly speaking visible in either Prud'homme-Farges's From my Window or in Arbid's Outside. Thus, both short films adhere to a continuing tradition overshadowed by the current focus on social media's practices of exhibition of the self: that of transferring body dynamics to the recording device which becomes responsible for making evident these outward-reaching gestures by translating them in technological and aesthetic terms. In Arbid's film, the author and the viewers are confronted with the unidirectionality of her peek from behind the window - there is no 'upward mobility' of the gaze, neither in the literal, nor in the social sense of the phrase. The limits of scopocentric and graphocentric strategies of asserting the self and communicating with the others become so pervasive that 
the situation requires a resolution through physical action; thus, on the occasion of one of the daily short outings allowed during lockdown, the filmmaker goes, phone in hand, towards her subject. The vagrant girl runs away, and her ambiguous reaction becomes material for even more speculations, as Arbid returns to her position of observer. Her privilege however, at least as a filmmaker, is greatly diminished: the girl leaves her spot, passing back only occasionally in front of Arbid's windows. The usual level of agency of filmmaker and subject, but also of socially integrated and marginal, is temporarily inverted, the former being forcibly bound to their possessions, while the latter enjoy a comparatively greater freedom of movement.

Jérôme Diamant-Berger proposes a shift away from private space and its specific model of visuality in his letter titled Inside (2020), composed exclusively of publicly accessible footage from surveillance cameras scattered around the world. Diamant-Berger adopts a contrastive approach, establishing two sorts of comparisons: between the type and degree of visibility the different excerpts confer to the pandemic, and between the actual images and the collective imagination forged in part by the official reports on the evolution of the situation, but above all by the latter's mediatic echoes. Most video surveillance footage is oriented towards the elucidation and systematization of the human flux, which is equivalent to dwarfing the individual, reducing it to a mere sign. The health crisis and its impact on human mobility and interactions, but more particularly the selection Diamant-Berger realizes from the multiple facets of the situation, as captured by the detached gaze of the surveillance apparatus, strengthen this tendency, to the point that Inside gives a glimpse of a non-anthropocentric world, yet still resolutely mediated by human sensibility (as DiamantBerger's authorship makes itself very strongly felt during the entire duration of the film, through incessant voice-over and music).

To a certain extent, Jérôme Diamant-Berger's film is making a political statement or at least one which has the potential to be politicized, as it recuperates an instrument of control which is being employed to monitor citizens (and even more intensely so in times of emergency), ${ }^{3}$ repurposing it in order to either contest official versions of the events, or to underline aspects which are being omitted in the latter. When the origin of imposed confinement is institutional, all investigations of its circumstances, all questioning concerning its validity are charged with political potential, as they unsettle the authority in the name of which such measures are being taken. In this diffuse sense, most objects of the chosen corpus are shaping their authors, but also their spectators, as political subjects, granting the sanitary crisis a

3 For a genealogy of the intersection between cinema and technologies of surveillance in urban hypermodernity, see Vincent Jacques, "La ville ubiquitaire: vision urbaine technique et cinéma," La Furia umana, no. 40, 2021, www.lafuriaumana.it/index.php/74-lfu-40/1010-vincent-jacquesla-ville-ubiquitaire-vision-urbaine-technique-et-cine-ma. Accessed 15 July 2021. 
revelatory capability consisting of exposing social inequalities and authoritarian tendencies hiding in the shadow of democracy. Discussing Jean Genet's carceral novels Notre-Dame des Fleurs and Miracle de la rose, Pascaline Hamon suggests that prison is a heterotopic space, defined by Michel Foucault as

[...] real places-places that do exist and that are formed in the very founding of society - which are something like counter-sites, a kind of effectively enacted utopia in which the real sites, all the other real sites that can be found within the culture, are simultaneously represented, contested, and inverted. (“Of Other Spaces” 3-4)

Thus isolated (and preserved) from the numbing rituals of functional, productive society, spaces of confinement become laboratories for reimagining the outside world. For example, the looming threat of disembodiment, of social fragmentation and desolidarisation that is evoked in Joël Farges's "cinematic letter" (From the Republic Square (On an Evening During Lockdown) / De la Place de la République (un soir de confinement) (2020) - which depicts one of the central points of popular protest against government decisions in the French capital, necessarily deserted during lockdownis countered by the possibility of the rise of a post-pandemic and post-neoliberal order. Farges references Chris Marker's photo-play La Jetée, at first only implicitly, through its predominant use of static images, and later by showcasing a fragment of the film. But most importantly, Farges aims to replicate La Jetée's temporal intricacies mainly by disrupting dominant assumptions of technological modernity as the backbone of our present and future, equating it instead with a reprehensible recent past that was finally ended by the raging epidemic. In a bewildering present where most social bonding activities have been ruled out, the filmmaker turns either towards the more distant past (such as childhood recollections filled with the buzz of insects gone extinct since then) or towards fleeting, puzzle-like memories of resistance in order to imagine the future. The overall tone of the film, ranging from an emphatically literary third-person narrative voice to the nostalgialoaded mentions of classic cinephilic experiences, is assumedly anachronistic, yet not entirely backward-looking. There is a touch of amusement in the vision of "a civilizational shipwreck brought about by a sneeze," as the narrator puts it, as well as a touch of hope to be found in the temporal uncertainty which stems from the spatial constraints of the lockdown. 


\section{The Implicit Other: (Self-)confinement Essay Films}

In the final part of my text, I will turn towards a cinematic phenomenon that can provide a set of tools for analyzing pandemic essay films: the audiovisual recording of the filmmaker's self-imposed isolation. Oftentimes, these works resemble a personal diary, without necessarily respecting its structural rigidity: entries may be sparse and diverse in length and content, and do not always make the temporal coordinates explicit. However, they aim to produce a painstakingly precise mapping of their authors' intimate becoming in conditions of social isolation and introspection, as well as a recording of their routine and physical environment. The juncture where these films diverge from the traditional filmed diaries is located not at the level of subject matter, filmic grammar or performative stance which are all common to a tendency David E. James calls "the domestication of cinema" (37), but at the one of negotiations with figures of alterity, both real (family members, friends and acquaintances who appear, either physically or just textually, in the film) and virtual (the spectator). As James notices:

[...] the domestication of cinema allowed an even more radical incorporation of it into life's most crucial transactions. If in telling its own story the visual tells all others, the exchange of vision between people becomes the means of social interaction; and so film - a means of seeing-becomes not just an instrument of personal documentation, or yet simply the means by which a subjectivity may be documented, but also the mode of a relationship's practice. The sign of intimacy becomes the medium of intimacy; the intercourse of sight is the site of intercourse. (37)

Yet there is no 'simple' means by which to document a subjectivity, as there is no subjectivity without the objectification of its possessor through the gaze of the Other (that can be otherwise physically absent). Filming is an objectifying process, and, as such, these diary recordings of social isolation formulate what the inmate's resistance to invisibilization also involves: a message addressed to other subjectivities that form the mysterious foreign body called society, on the outside of which the authors of these films are temporarily or permanently situated. Maybe more so than in conventional diary films, the other is the hidden subject. Instead of oscillating between interiority and exteriority, balancing the space and time allocated to the 'I' and to the 'they,' self-confinement films are entirely focused on the only direct and yet secured opening towards the outside world which is at their filmmakers' disposal: the film frame. Such centrifugal tendencies, characterized by a fearful, yet paradoxically inviting attitude, are visible for example in Anne Charlotte Robertson's Five Year Diary (1981-1997), a hybrid, complex work that compiled fragments of decades of the filmmaker's life, chaotically and poetically reflecting her experience of bipolar disorder. 
In the film as well as in the screening notes accompanying it, Robertson repeatedly referred to her recordings as a "trousseau" for her "one true love" (Gouws 115-16) - a romanticized formula expressing the crave for a dialogical, or at least an exterior monological situation.

Discussing the technological and phenomenological redefinitions of self-image brought about by the extensive use of videoconferencing tools during the pandemic, Yvonne Zimmermann cites Christian Metz, who used to point out that "film is [ ...] different from the natural mirror in one important respect: although everything can reflect just as well in the former as in the latter, there is one thing that will never find its reflection in film, namely the spectator's body. From a certain point of view, then, the mirror suddenly becomes opaque" (45). Through their chronicle of everyday existence, diary films have frequently aimed to dissolve the border between creator and viewer, and as such, to circumvent Metz's statement by reflecting the author's body in place of the spectator's. Pandemic essay films continue this tradition, under the new impulse of the upheaval of stable conceptions of the self caused by the impact of the global health crisis on traditional forms of communication and sociability. A film such as Emily Holmes's “cinematic letter" Sensorial mappings of the confined specimen (Cartographies sensorielles du spécimen en confinement, 2020) directly addresses the potential of the (web) camera to act as a 'memory mirror,' both reflecting the event as it happens and transforming it into an accessible archive, into a future past moment. As its title indicates, Holmes's essay starts as a survey of the observable changes taking place in a body subjected to confinement. The attempt is complicated by the fact that the body in question belongs to a dancer who, both symbolically and pragmatically, makes a more extensive use of it than most other socio-professional categories and, as such, also needs a space that can accommodate this usage. Instead, Holmes decides to execute a series of minimal dance moves in the contiguity of her room, facing the camera, at various angles that further compress the already limited space. The large depth of field of the camera turns the different planes of the image into one crisp, flat surface, and transforms Holmes's figure, uncomfortably crouched in front of her device, into an almost pure graphic element.

Undoubtedly, there is also a strong sensual dimension to Holmes's blend of dancing, medical self-examination and mirror-gazing, which interrogates the link between intimacy and performativity, between actual, physical solitude and perceived community. Such a handling of these issues leads us once again towards Anne Charlotte Robertson's Five Year Diary and its reinterpretation of second-wave feminist concerns and body art as seen in Eleanor Antin's, Andrian Piper's or Carolee Scheenmann's living oeuvres. ${ }^{4}$ Robertson

4 For a contextualization of Anne Charlotte Robertson's Five Year Diary in relation to feminist art of the 70s, see Anjo-mari Gouws, Recording the Work of a World. Anne Charlotte Robertson's Diary Film and the Domestication of Cinema (unpublished doctoral thesis, University of Toronto, 2020). 
delimitates herself from these models not only because her perspective is much more infused with a classical heterosexual understanding of issues of gender and sexuality, but also due to the fact that she spends most of her time on her own, in a private, secured space, which is however a theatre scene of sorts. But here, the audience is fantasized, its reaction is deferred, imprecise, yet decisive for the subject's behavior. As the inside of her home becomes an outside, offered to the spectator's gaze, Robertson's unfeigned intimacy becomes the spectacle, resonating with Stan Brackage's assertion that "[he was] guided primarily in all [his] creative dimensions by the spirit of the home in which [he was] living, by [his] very own living room" (Brakhage and Haller 168).

In the reclusion imposed by the pandemic, space regains the central position it had arguably lost in the era of temporal technological media. Private space becomes social and even communal as it ceases to be reserved to 'the authentic self' and becomes the hub of all activities accomplished by the individual subjected to home confinement. While the temporal borders between professional and private life were already blurred, not least by the omnipresence of communication devices which established a permanent state of availability to the outside world, the spatial dimensions associated with different personas and statuses remained separate. Emily Holmes's Cartographies tackles the collapse of this spatial division, echoing the work of filmmakers such as Chantal Akerman or Agnès Varda who have reappropriated the domestic universe, historically considered as being 'feminine,' and who have endeavored to make it an area of creative freedom and of unrepressed, non-androcentric sensuality.

Even when it is not visible, as the camera is permanently pointed out towards the desired outside world, interior space-where the "cinematic letters" are conceived, filmed and even edited, as the filmmaker frequently endorses all the roles in the production chainis shaping the creative process through "its quality as a space that is at once embedded in, and discontinuous with the exterior, and with itself" (Lajer-Burcharth 438). In this respect, confinement may resemble an illumination: it transfigures the trivial details of the most familiar environments, taking off the strata of habitualness our distracted modes of engagement had covered them with and infusing them with an everyday hyperreality. ${ }^{5} \mathrm{~A}$ remarkably simple example in this sense is Clément Schneider's Letter to the Cinémathèque I Lettre Cinémathèque, 2020), which opens with a series of white titles on a black screen. The text states the filmmaker's initial desire to compose an imageless and soundless film, as an act of defiance towards the flood of information that has been pouring from screens since the start of the pandemic. But the global crisis, which challenged the capacity of visual representation to materialize and authenticate the unperceivable, to replace physical contact

5 See Ivone Margulies, Nothing Happens: Chantal Akerman's Hyperrealist Everyday (Duke University Press, 1996). 
and act as the main container and transmitter of our presence in the world in the absence of the concretizing gaze of the other, is finally best defined, in Schneider's opinion, by the antispectacular image. By filming the shadow cast by a lamp on the wall, Schneider creates what I could call with Chrysanthi Nigianni an "image of suspension," (no pag.), yet I would have to part with the author's definition of the notion. In her analysis of Akerman's Là-bas, a film composed predominantly of static shots filmed from the inside of Akerman's Tel Aviv apartment, Nigianni defines the image of suspension as a specific type of thinking-image that

[...] by giving time an ontological priority, [...] breaks away from a valorisation of visuality, which has historically supported the privileging of space over time (psychoanalytic concepts of scopophilia, voyeurism, and the gaze are still dominant and key terms in order for us to think of the cinematic image), [hence becoming] an image that does not serve (re)cognition and thus does not command action, but persists and endures as the power to be affected; an image that speaks without giving orders, without claiming to represent anything; an image that requires from us solely to acknowledge the appearing of time as the only event. (no pag.)

It could also be argued however that space is given a similar, if not greater ontological weight and that it is its invariability, its substantial existence, that allows for the observable emergence and unfurling of time. The higher density of the temporal flux during home confinement is subordinated to the reduction of space and its subsequent transfiguration under the gaze that has been absolved of the function of absorbing and making sense of a multiplicity of constantly varying sights. For this transfiguration to occur, though, one is supposed to disconnect from the über-window constituted by the digital screens and to fix upon one's immediate surroundings, precisely as surfaces that harbor no predetermined signification. Schneider's choice of a shadow, which is one thing virtual objects cannot cast, acts as a rebuttal of the allegory of the cave, in affirming that shadows are no deceptions, but proofs of existence of a material reality to which we should pay greater attention, during and especially in the aftermath of the pandemic.

\section{Conclusion}

The Greek word krisis refers to a critical moment that demands a decision, a severing of the continuity between past and present. Despite the limited hindsight we have at this point, we can already affirm that the pandemic does not seem to have been a crisis in this sense, but rather a revealer of dormant or hidden tendencies and forces already working at the reshaping of our modes of being. The novelty of the economic stoppage, the travel bans and the mandatory home isolation has been counterbalanced by the ease of access to 
an uninterrupted digital flow of professional as well as amateur instant documentation on the various facets of the crisis, but also to plentiful information about past situations that could serve as emotional anchor points and offer reading grids for a disconcerting present. The carceral experience and self-isolation diary films are only two possible entry points for analyzing pandemic essay films. The normalization of the epidemic state of emergency due to the persistence and adaptability of the virus should not deter film scholars from approaching anew the manifestations of a configuration of the essay film genre which I believe will not simply endure as historical document of an exceptional global context, but as manifestation of a previously very rare type of record: the cinematic capture of externally-imposed confinement, made by those directly affected. Considered collectively, these audiovisual works lead to an enlargement of the thematic concerns and the discursive strategies of the essay film, thus confirming the acuity and the receptivity of the genre when it comes to articulating the shifting relations characterizing the triad image-self-society.

\section{Works Cited}

“2011: état des lieux sur la place de l’image en milieu pénitentiaire.” CNC, Dec. 2011. imagesdelaculture. cnc.fr/web/guest/-/2011-etat-des-lieux-sur-la-place-de-l-image-en-milieu-penitentiaire?inheritRe direct=true. Accessed 9 July 2021.

Alter, Nora M., and Timothy Corrigan, editors. Essays on the Essay Film. Columbia University Press, 2017.

Brakhage, Stan, and Robert A. Haller. Brakbage Scrapbook: Collected Writings, 1964-1980. New Paltz, 1982.

Breytenbach, Breyten. True Confessions of an Albino Terrorist. Faber and Faber, 1984.

Deshpande, Shekar. "The Ontology of Windows and Cinema in the Pandemic: e-flux and International Short Film Festival Oberhausen's Film Series 2020.” Senses of Cinema, May 2021,www.sensesofcinema.com/2021/feature-articles/the-ontology-of-windows-and-cinemain-the-pandemic-e-flux-and-international-short-film-festival-oberhausens-film-series-2020/. Accessed 14 July 2021.

Five Year Diary (1981-1997). Directed by Charlotte Robertson. The Harvard Film Archive.

Fleetwood, Nicole R. Marking Time: Art in the Age of Mass Incarceration. Harvard University Press, 2020.

Foucault, Michel. Discipline and Punish. The Birth of the Prison. Translated by Alan Sheridan. Random House, 1995.

—. "Of Other Spaces: Utopias and Heterotopias." Architecture /Mouvement/ Continuité, October 1984. Translated by Jay Miskowiec.

Freeman, Thomas S. “The Rise of Prison Literature.” Huntington Library Quarterly, vol. 72, no. 2, 2009, pp. 133-46. 
From My Window / De ma fenêtre. Directed by Olga Prud'homme-Farges. Self-produced, Cinémathèque Française Vimeo account, 2020.

From the Republic Square (On an Evening During Lockdown) / De la Place d la République (un soir de confinement). Directed by Joël Farges . Self-produced, Cinémathèque Française Vimeo account, 2020 .

Gouws, Anjo-marí. "Recording the Work of a World. Anne Charlotte Robertson's Diary Film and the Domestication of Cinema.” PhD. Thesis. University of Toronto, 2020.

Hamon, Pascaline. "Notre-Dame des Fleurs et Miracle de la rose, de Jean Genet. L'écriture mise au secret," Les Dossiers du Gribl (2011), https://doi.org/10.4000/dossiersgrihl.5000. Accessed 15 July 2021.

"Image à voir, image à faire, guide de l’image animée en milieu pénitentiaire." cnc.fr, June 2013. www. cnc.fr/professionnels/etudes-et-rapports/image-a-voir-image-a-faire--guide-de-limage-animee-enmilieu-penitentiaire_222581. Accessed 9 July 2021.

Inside. Directed by Jérôme Diamant-Berger. Self-produced, Cinémathèque Française Vimeo account, 2020.

Jacques, Vincent. "La ville ubiquitaire: vision urbaine technique et cinéma.” La Furia umana, no. 40, 2021. www.lafuriaumana.it/index.php/74-lfu-40/1010-vincent-jacques-la-ville-ubiquitairevision-urbaine-technique-et-cine-ma. Accessed 15 July 2021.

James, David E. Allegories of Cinema. American Film in the Sixties. Princeton University Press, 1989.

Kittler, Friedrich. Gramophone, Film, Typewriter. Translated by Geoffrey Winthrop-Young and Michael Wutz. Stanford University Press, 1999.

Keidl, Philipp Dominik, Laliv Melamed, Vinzenz Hediger, and Antonio Somaini, editors. Pandemic Media: Preliminary Notes Towards an Inventory, Meson Press, 2020.

Là-bas. Directed by Chantal Akerman, AMIP, Paradise Films, Le Fresnoy, 2006.

Lajer-Burcharth, Ewa. "Unbelonging Interior. Chantal Akerman's Là-bas," Interiors and Interiority, edited by Ewa Lajer-Burcharth and Beate Söntgen. Walter de Gruyter, 2016, pp. 435-55.

La Jetée. Directed by Chris Marker. Argos Films, 1962.

Larson, Doran. “Toward a Prison Poetics.” College Literature, vol. 37, no. 3, 2010, pp. 143-66.

Letter to the Cinémathèque / Lettre Cinémathèque. Directed by Clément Schneider. Self-produced, Cinémathèque Française Vimeo account, 2020.

Margulies, Ivone. Nothing Happens: Chantal Akerman's Hyperrealist Everyday. Duke University Press, 1996.

Méchoulan, Eric. "Les écrits de prison et la microphysique du pouvoir." Les Dossiers du Gribl, 2011, https://doi.org/10.4000/dossiersgrihl.4875. Accessed 14 July 2021.

Metz, Christian. The Imaginary Signifier: Psychoanalysis and the Cinema. Translated by Celia Britton and Annwyl Williams. Indiana University Press, 1986.

Nigianni, Chrysanthi. "Chantal Akerman's Là-bas: The Suspended Image and the Politics of AntiMessianism.” Senses of Cinema, no. 67, July 2013. www.sensesofcinema.com/2013/featurearticles/chantal-akermans-la-bas-the-suspended-image-and-the-politics-of-anti-messianism/. Accessed 20 July 2021. 
Outside. Directed by Danielle Arbid. Self-produced, Cinémathèque Française Vimeo account, 2020. Sensorial Mapping of the Confined Specimen / Cartographies sensorielles du spécimen en confinement. Directed by Emily Holmes, Self-produced, Cinémathèque Française Vimeo account, 2020.

Tschanz, Anaïs, and Lucie Hernandez. "Understanding the Carceral Experience and the 'Carceral Imaginary' in a Lockdown Situation: An Exploratory Study of Social Representations of Prison during a Heath Crisis." Annual Review of Interdisciplinary Research, vol. 10, 2021, pp. 143-71, https://canlii.ca/t/t9ht. Accessed 3 Dec. 2021.

Zimmermann, Yvonne. "Videoconferencing and the Uncanny Encounter with Oneself: SelfReflexivity as Self-Monitoring 2.0," Pandemic Media, edited by Philipp Dominik Keidl, Laliv Melamed, Vinzenz Hediger, and Antonio Somaini, pp. 99-103. 